\title{
Looking Through the Multicultural Glass: Re- Examination of Syrian Refugee Children Education in Turkey
}

\author{
Melike Ünal Gezer a * \\ ${ }^{a}$ TED University, Ziya Gökalp Cad. No: 48, Kolej, Çankaya, Ankara, 06420
}

Received 23 March 2019 | Received in revised form 10 June 2019 | Accepted 30 July 2019

\author{
APA Citation: \\ Ünal Gezer, M. (2019). Looking through the multicultural glass: Re-examination of Syrian refugee children education \\ in Turkey. Eurasian Journal of Applied Linguistics, 5(2), 303-322. Doi: 10.32601/ejal.599275
}

\begin{abstract}
Turkey presents a unique picture as the host of the highest number of Syrian refugees after the outbreak of civil war in Syria in 2011. According to United Nations High Commissioner for Refugees (2018), Turkey has more than 3.5 million Syrian refugees half of whom are school-aged children. These children have limited access to their basic human right: receiving quality education. Fewer than half of approximately one million school aged (ages 5 to 18) Syrian refugee children could receive regular education services in Turkey (Directorate General of Immigration Affairs, 2016). Turkey welcomed a large number of Syrian refugees without taking necessary steps in its education system. Embracing cultural diversity via multiculturalism, and multilingual education, one needs to direct the attention of the audience to the long-term struggle of refugee children in Turkish education system and draw a conceptual framework for quality education and excellence in teacher education. The present paper is an attempt to highlight the role of multicultural education; more specifically through the lens of multicultural literacy practices. Highlighting the contributions of various genres of different ethnic and racial backgrounds such as songs, poetry, fiction, (auto)biographies, multicultural literacy could increase cultural awareness and understanding of pupils, teachers, administrators and the communities, and could help establish enriching learning experiences for Turkish and Syrian children. Multicultural literature provides a meaningful platform affirming differences and showing cultural connections, revealing social issues, necessitating action against injustice, and embracing diverse cultures. When implemented with care, multicultural literacy could increase academic achievement of ethnic minority and at-risk students, heighten cultural awareness and understanding of all students, and provide meaningful learning opportunities for all. The present paper aims to delve into the relationship among English as a lingua franca, Syrian refugee children education, and the theoretical underpinning of multicultural and multi-ethnic education in relation to English language instruction in Turkey.
\end{abstract}

(C) 2019 EJAL \& the Authors. Published by Eurasian Journal of Applied Linguistics (EJAL). This is an open-access article distributed under the terms and conditions of the Creative Commons Attribution license (CC BY-NC-ND) (http://creativecommons.org/licenses/by-nc-nd/4.0/).

Keywords: English as a lingua franca; refugee children; Syrian; multicultural education, ELF

\footnotetext{
* Corresponding author. Tel.: +90-312-585-0329

E-mail address: melike.gezer@tedu.edu.tr
} 


\section{Introduction}

Since Syrian crisis began, Turkey, a signatory to 1951 Geneva Convention and 1967 Additional Protocol, has adopted an 'open door' policy for Syrians and welcomed the majority of Syrian refugees compared to other nations. In 2011, 2.5 million Syrians fled to neighboring countries and by 2015 this number went up to 4 million, 2.5 million of which residing in Turkey. In October 2011, Turkish government adopted a temporary protection regime for all Syrians ensuring nonrefoulment protection, humanitarian assistance and no limit on the length of stay in Turkey. With the passing law on Foreigners and International Protection in 2013, Syrian nationals in Turkey secured a lawful stay in Turkey until the end of conflict in Syria and have access to education. (Şimşek, 2019).

Up to 22 million inhabitants of Syria have been forced to flee their homes, temporarily or permanently since 2011 (İçduygu \& Sert, 2019). The influx of refugees between April 2011-2016 resulted in a total of 2.834.441 newcomers seeking provisional protection status in Turkey (Directorate of Immigration Affairs, 2016). While the number of Syrian refugees was around 2,8 million in 2016, according to Syrian Refugee Organization in Turkey (2019), the most-up-to-date Syrian population is 3.632 .622 ( 1.970 .837 males and 1.661 .785 females) that is $3.6 \%$ of Turkey's overall population. According to the same resource, about half of the refugee immigrant population in Turkey consists of 1.649.236 school-age children (see Table 1).

\subsection{Syrian refugee children at Turkish education system}

Sidhu and Taylor (2007) reported the lack of policy specifically targeting at refugee students in Australia as they are either regarded as ESL or ignored altogether. Arnot and Pinson (2005) listed the needs of refugee students in the major areas: learning, social, and emotional. More attention is needed in facilitation of development of other skills and knowledge functional for their resettlement. However, the main emphasis of the education system is language issues (ESL for Australian context). Taşkın and Erdemli (2018) recently presented similar cases of Syrian refugee children, who are attending Turkish state schools, having to copy-paste Turkish sentences with no meaningful learning opportunities. United Nations High Commissioner for RefugeesUNHCR- issued a report in 2018 informing 40\% of Syrian refugee children were not attending school. Turkey has allowed Syrian refugee children to attend public schools at primary and secondary levels. At present, more than 212, 000 refugee children are currently enrolled in Turkish primary and secondary schools (Aydın \& Kaya, 2019).

OECD (2008) mandates fairness and inclusiveness should be essentials for equitable education. Fair and inclusive education system could make the benefits of education available to all. Providing quality, equal educational opportunities is the essential task Turkey should ensure as the host country; however, as Şirin and Aber (2018) reported only 10\% of school-aged Syrian refugee children received education in 
refugee camps. According to the report, over 500.000 Syrian children between ages 0 to 6 did not receive formal education. According to TÜRKSAM Immigration Bulletin (2019), the number of Syrian refugee children receiving education in Turkey was around 606.000 with 100.000 attending temporary education centers (TECs) and 500.000 attending Turkey's Ministry of National Education programs (see Table 1).

Table 1. Syrian refugee children population

\begin{tabular}{llll}
\hline \multirow{2}{*}{ Programs } & \multicolumn{2}{c}{ Gender } & Total \\
\cline { 2 - 4 } $\begin{array}{l}\text { Preschool } \\
\text { Ages 0-4) }\end{array}$ & 231.702 & Male & 480.154 \\
$\begin{array}{l}\text { Primary } \\
\text { (Ages 5-9) }\end{array}$ & 245.168 & 260.848 & 506.016 \\
Secondary & & & \\
(Ages 10-18) & 311.400 & 351.666 & 663.066 \\
Tertiary & 229.287 & 320.235 & 549.522 \\
(Ages 19-24) & & & \\
& & & $* 2.198 .758$ \\
\hline
\end{tabular}

*Total number is for all age groups which is \%60.5 of overall Syrian population in Turkey in 2019

\section{Literature Review}

\subsection{Turkey: through the lenses of bilingualism and language planning}

Examples of nations receiving a large influx of immigrants, refugees fleeing from discrimination and oppression are numerous in the world. Kaplan and Baldauf (1997) discussed degrees of bilingual competence: minimal bilingualism with a dominance of L1 or L2 and balanced bilingualism with no clear dominance of one language over the other. When Turkey's actions in taking the necessary steps in language-in-education planning are compared to the theoretical model by Kaplan and Baldauf (1997), one can notice that necessary stages for a functional education policy have not been taken. For instance, in the preparation stage, the essential steps such as pre-planning, personnel and materials policy to be taken but there is slight evidence that Turkey took all these steps to prepare the necessary infrastructure to welcome refugees and integrate them to the society and education.

From the dichotomy of assimilationist and pluralistic motives (Baker, 2011), values, and politics could result in different immigrant integration processes. Assimilation of newcomers into the host culture and language via systematic practices is one end of this dichotomy and celebration of ethnic diversity, multilingualism with no domination of one group over another is the other end. According to Cummins (2000), 
the following characteristics of schools either empower or hinder language minority students:

1. Incorporation of minority students' home language and culture

2. Encouragement of integration of minority communities to minority children's education

3. Promotion of inner desire for children to become active learners

4. Evaluation of the pressing issues causing minority students problems.

The essential question is whether multicultural literacy practices could establish a baseline for an integrative education system for Syrian refugee children in Turkey. To further the discussions on this, some key concepts are defined in this section.

\subsection{Language diversity}

Linguistic diversity denotes the existence of a multitude of languages spoken in the world which is more pervasive in some parts of the world (i.e. Papua New Guinea) compared to others such as Iceland. Regardless, there is need to consider the specific needs of children in respect to the language(s) at home and in the school context.

\subsection{Minority language}

It is an ambiguous term that has different interpretations depending on the country with its political and social dimensions. In Turkish context, Syrian refugees immigrated to Turkey are regarded minorities due to numerical count as well as the political and social dominance in the host country. Syrian Arabic is the minority language while Turkish is the majority language.

\subsection{Official vs national language}

In the globe, there are states with more than one official language (India is exemplary country with multiple official languages) and exceptions with no official language (United States of America has no de jure language- English is the de facto of the USA). Recognizing a language for compulsory education bestow a privilege on this language as the language of prestige, power, and status.

The language of instruction is the linguistic choice for administering basic curricular activities in the educational system. Even though there are languages offered in the education system of a nation, the choice of the language(s) poses a challenge in the sustainability of quality education. The contemporary world is abundant with examples of countries giving a strategic role to national or local languages a crucial role in schooling. The speakers of languages that are not the nationally or locally accepted are at a disadvantage in the educational settings. A child's emerging experiences in native language may not overlap with that of formal instruction (i.e. Kurdish pupils in Turkey). The perils of this is that learners will end up learning a new language and build knowledge and skills around this language. The 
perils are major for refugee minorities, especially for female students who are often trapped between the cracks of traditional societies, male hegemony holding back from their utmost right: receiving education.

\subsection{Additive vs subtractive bilingualism}

UNESCO supports mother tongue instruction as a means of improving educational quality by building on the knowledge and experience of learners and teachers. It supports bilingual and multilingual education at all levels of education as a means of promoting linguistic diversity.

Mother tongue instruction is key to emergent literacy development which could be extended to later stages of education. Literacy could be maintained only if there is an adequate supply of reading material for school children for educational and recreational purposes. The Directorate of Immigration Affairs under Turkey's Ministry of Interior (2016) published a strategy document listing steps to be taken for Turkey's accession to the European Union and initiations to regulate Syrian refuge.

Students with limited English proficiency, in the United States, has been the center of attention of researchers and policy-makers. In the U.S. context, if students cannot participate in instructional practices in a meaningful and equitable manner in the English-only school environment due to their limited English proficiency, they are qualified for special services such as English as a second language, content-based ESL, sheltered instruction, structured immersion, and three types of bilingual instruction programs: a) transitional, b) maintenance, c) two-way bilingual programs. Such services are providing instruction in the mother tongue, education and training in the non-native language with reduced load. Children of language minority should be granted opportunities to express themselves and communicate in the mother tongue first and then slowly move to the official or national language of the country. Freely accessible materials on language education and language teaching in virtual platforms are some of the possible routes to follow for a comprehensive and welcoming educational setting.

Inter-cultural education to promote understanding between different population groups and respecting human rights is the key to successful integration of minority students to our education system. The rights of Syrian refugee children could be ensured via mother tongue instruction and culturally responsive teaching methods. Additionally, teaching of and through mother tongue in addition to official and global languages could enhance the minorities' integration to the community. Education with an increasing awareness of positive value of cultural and linguistic diversity via curricular choices that are inclusive and positive to the minority language culture, language and identity is an urgent need of this age. Language teaching is not mere linguistic exercises, instead, it is to gain deeper understanding of other cultures, reflections of other ways of life, and customary behaviors. 


\subsection{Biliteracy}

Biliteracy denotes the capacity in which communication takes place in two or more languages through writing (Hornberger, 2003). Among the numerous advantages of biliteracy are the transfer of some of the skills mastered in L1 such as vocabulary, decoding, fluency, and attitudes toward literacy practices such as reading and writing. In addition to such individualistic level benefits, societally speaking, the minority language gains status and increased functions. If minority language is only for oral communication purposes but not for literacy events, it has lower status and may have a lower chance of survival. In Turkey, Syrian refugee children are expected to have communicative and literacy skills in Turkish so it is an example of double loss of prestige and function of Syrian Arabic of minority students.

\subsection{Refugee children integration: assimilation or acculturation?}

Integration is a chaotic concept used and understood differently by many. Refugee integration is a dynamic process which is established based on different means which are employment, housing, education, facilitators such as language and culture, and foundational rights.

Assimilation which often recalls negative connotation such as the loss of identity and ethnic background. Acculturation; however, is the middle ground between the visiting and the host people, it is like meddling point of cultures, traditions, norm and values. It is not the host country making the visitors to assimilate but the visitors having an impact over the host society too. Current literature exemplifies the cases of Syrian and Turkish natives trying to find a middle ground. Gürsoy and Ertaşoğlu (2019) investigated the perceptions of Syrian refugees of Turkish as a second language and found out the participating sample, despite variations across gender and age groups, had a positive perception of Turkish as the second language and Turkey as the host country. Aydin and Kaya (2019) conducted a study with teachers and school principals and reported cases where in-service teachers offering additional Turkish coursework over the weekend and the same teachers taking Arabic courses to facilitate communication with refugee children in their mother tongue.

\subsection{Refugee children education in Turkey}

Syrian students have the right to receive education in the same class with Turkish peers. Syrian children, without a preparatory year, were admitted to formal classes offered in Turkish. According to Human Rights Watch Report (2015), more than 36,000 Syrian children registered at primary, middle and high schools in Turkey in 2014-2015. For education of Syrian refugee children, Turkey's Ministry of National Education (MONE, 2016) has offered two options: a modified version of Syrian curriculum offered in Arabic in the camps via national school system, TECs supported by United Nations Children's Fund (UNICEF) which are transitional education centers to integrate Syrian children to Turkish systems. These centers are planned to 
provide short term educational alternative with Arabic medium instruction modeling after Syrian curricula. Syrian refugee enrollment is still low with a $0.22 \%$ of the total in-school population in Turkey due to language barrier, the need for residency permit which requires a lengthy residency in Turkey.

While Turkey has the assimilationist viewpoint, the plans have failed because it has been reported many refugees did not view Turkey as their final destination so they did not perceive Turkish as a language that needed to be acquired urgently. According to Aydın and Kaya (2019), there is no effort to teach English to Syrian children because there was not enough number of English language teachers who could teach English at public schools and TECs. Banks (2008) mentioned the challenge of multilingual societies face in securing spaces for diverse populations. Even though Turkish government is welcoming, inclusive classrooms and a sense of belonging among Syrian refugee children should be established. Turkey's temporary protection regime; however, provides an unsustainable system for Syrian children.

Turkey's MONE has policies to help and educate Syrian children yet they have not set a specific program to public schools for Syrian children in Turkey. Aydın and Kaya (2019) informed Syrian families opted for enrolling their children in TECs because these centers' education promote home culture and language.

Revealing pressing issues of Syrian refugee children in Turkish education system, Taşkın and Erdemli (2018) reported learning all about Turkish grammar and copypasting sentences with no communication and comprehension is one dimension and Syrian family resistance against Turkish learning is another. Lack of curriculum, teaching material, instructional expertise in the education of foreigners via Turkish education system are several other dimensions taking Turkey to failure in the education of Syrian refugee children. It is not fair to put Syrian and Turkish children into the same classroom and expect them to perform similarly. Keeping Syrian children to be responsible for the same curriculum and materials is not just due to the language barrier. Turkish language teaching is the key that would unlock consecutive issues and it should be done in a communicative and functional way so Syrian children do not merely copy and paste sentences.

The need for further research to explore ways to reduce barriers to refugee children's learning is recently reported and bridges between refugee children education through multicultural and Arabic-Turkish bilingual education (Aydin\& Kaya, 2019) can be a solution to a) train teachers and counselors more effectively, b) reach out more refugee children and families, c) increase quality of education, curriculum and instruction that is more accessible and sustainable.

Turkish Constitution secures every child's right to receive education and according to UN's Convention on the Rights of the Child, to receive education is one of the most essential rights of refugee children. According to Skutnabb-Kangas (1981; 2000), it is basic human rights for every child to receive the opportunity to develop the language first, to develop full native mastery, to be proud of it and to be able to use it for all purposes for official and non-official contexts. Although the juridical decisions 
mandate the educational endeavors of refugees are bound to blanket clauses, Turkey is still evaluating effective solutions to the needs and necessities of this age where she [Turkey] is multilingual, multi-ethnic and multicultural more than ever. As of 20162017 academic year, Turkish government mandated all pre-school and first grade students attend public schools instead of temporary education centers.

\subsection{Multicultural education re-defined}

Multiculturalism has become a tangible discussion in the matters of "globalization, transnational mobility of the population, and the spread of new technologies... in different political, social, and educational contexts" (Cenoz, 2013, p. 4). Multiculturalism is no longer the indication of a balanced mastery in two languages (Skutnabb-Kangas \& McCarthy, 2008). Learning and teaching is re-defined in light of such diversity across the world. Sensitivity to racial, ethnic, cultural, social, educational, religious, sexual, age differences and disabilities is in the core of multiculturalism.

Multicultural education, for a long time, has been problematized and undermined as a focus on food, holidays to recognize different ethnic and racial profiles. It is beyond this as in the essence, diversity, differences, individuality, respect exist. May (1994), with a skeptical take on multicultural education confronted "multicultural education may be, arguably, more benign than its assimilationist and integrationist predecessors but, beyond its well-meaning rhetoric, it is no more effective. It simply continues to perpetuate, in another guise, a system of education which disadvantages minority children (p. 35-36).

"Multicultural education is a reform movement designed to bring about a transformation of the school so that students from both genders and from diverse cultural, language and ethnic groups will have an equal chance to experience school success" (Banks \& Banks, 2010, p.25). The authors asserted regardless their sexual, ethnic, racial, cultural and any other orientations, educational opportunities should be equal to all students. In the heart of multicultural education are tolerance to diversity and equity for all. Multicultural education is to eradicate prejudice and increase communication with different cultures. It enlightens our ways by providing a perspective to the learners, reminding them personal and cultural experiences establish the essence of learning. Pluralistic viewpoint adoption in order to ensure different racial, cultural, linguistic groups could experience equal educational opportunities sets the essence of teacher education in multicultural education.

The following are multicultural dimensions applicable to teaching practices, curriculum design, teacher education, school environment and attitude of the society. 
Figure 1. Pillars of multicultural education

Monolingualism, monocentrism have long been replaced by multilingualism, multiculturalism, and pluricentrism (Seidlhofer, 2001). In the contemporary discussions of such glocalized world exist shifting foci from native-speaker oriented norms (e.g. accurate pronunciation) to non-native(ness) and intelligibility. The repercussions of such discussions paved the way to numerous in-service teacher education in awareness raising in English as Lingua Franca- ELF- that transformed the perspectives of English language instructors, their roles and functions (Bayyurt \& Sifakis, 2015a; 2015b; Jenkins, 2006) and the role of teacher education programs in the development of ELF related ELT teacher perceptions and attitudes (Biricik Deniz, Özkan, \& Bayyurt, 2016).

Currently, Syrian refugee children are offered two alternative programs: an adaptation of Turkish curricula offered in Arabic at TECs and secondly through formal education in Turkish which is regulated according to Turkey's Ministry of National Education. While Taylor and Sidhu (2012) suggest school plays a rather critical role in sheltering the development of a sense of belonging and adaptation of the refugee children, the reporting of a group of in-service teachers in Turkey address that the linguistic barriers cause either limited amount of communication or complete loss of communication between Syrian and Turkish students and thus the isolation of Syrian refugee children receiving formal education in Turkish (Uzun \& Bütün, 2016).

Numerous NGOs are helping Syrian children with Turkish education system with training to help children who are studying in language training centers and public schooling settings to understand Turkish school system and learn Turkish so they are ready for Turkish mainstream schools and become functional in society. Integration 
processes have different venues and education is the most effective tool for full integration (Çelik \& İçduygu, 2019).

\subsection{Can ELF serve as a common ground?}

The present paper aims to delve into the relationship among ELF, Syrian refugee children in Turkey, and multicultural and multilingual education as a cornerstone to Turkey's refugee children education. In this age, the "orientation of TEFL... is fundamentally shifted: from correctness to appropriateness, from parochial domesticity and exclusive native-speaker norms to global inclusiveness and egalitarian license to speak ways that meet diverse local needs" (Seidlhofer, 2001, p. 135) and such transformations in language education could help linguistically and culturally diverse children receiving education in Turkey. Providing the basis of promoting cross-cultural understanding in an increasingly global village (McKay, 2004), English can serve as a common ground that can serve a crucial role to close the linguistic, cultural gap between Syrian and Turkish pupils. Bayyurt (2012) described the relationship between concentric circles of Kachru (1985) and the impact of this on English language education by stating English is offered as a second or additional language in outer circle countries and as a foreign language in the expanding circle countries mimicking Kirkpatrick's (2010) definition of expanding circle "countries where English was traditionally learned as a foreign language in which English played little to no administrative or institutional role" (p.2). In a series of reforms, one stage supporting multilingualism and pluralism in foreign language education has been observed in Turkey. Bayyurt (2012) recommended English as an international language as the future of Turkey.

\subsection{English language teacher education in Turkey: multicultural and multilingual settings}

For quality education to shelter the needs of refugee children and the Turkish counterparts, it is Turkey's utmost obligation to support those instructors teaching in multilingual settings with Syrian-Turkish children. According to Blair (2015): "The 21st century speaker/user of English, regardless of their first language, can no longer be seen on simplistic, one-dimensional terms based on 'nativeness' or idealized notions of linguistic competence: the ever-moving pedagogical target can be imagined as 'beyond native' competence, with no 'final state' to the acquisition process (p. 91). In ELF contexts, there are no native speakers but multi-competent users (Pennycook, 2008).

Bayyurt and Akcan (2015) advocated in-service and preservice teacher education with effective ELF-inspired practices that leads to teachers who are able to cope with culturally and linguistically diverse student groups. Along these lines, Bektaş Çetinkaya and Börkan (2012) recommended intercultural communication instruction that would help teachers develop skills and knowledge enabling them gain specific understanding of beliefs and behaviors of minority groups. Following an ELF 
approach in language classrooms necessitates the adoption of a constructivist dimension in English language teaching challenging constructs like native speakerism, reconsidering 'inner circle countries' and critically analyzing the cultural content of language teaching materials, and reflecting on self and other cultures (Azuaga \& Cavalheiro, 2015).

Multicultural teacher education initiatives are being made via tele collaboration projects where participating pre-service teachers share their views of multiculturalism and multicultural education (Üzüm, Yazan, Avineri, \& Akayoğlu, 2019).

Llurda, Bayyurt, and Sifakis (2017) inform that non-native teachers demonstrate high levels of linguistic awareness due to second language learning experience. In order to provide quality English language education for Syrian and Turkish children, the remaining section of the paper aims to extend some of the concepts Bayyurt (2013) and Doğançay-Aktuna (2006) conceptualized to enrich sociolinguistics nature of language learning and instruction. More specifically, teacher education filtered through the lenses of multicultural education (Nieto, 2001) which is based on the Banks's (1998) multicultural education: content integration, knowledge construction, critical thinking and reading, reducing prejudice and stereotypes, and lastly empowering school culture and social structure will establish the basis of our discussions.

In plurilingual societies, multilingualism is a way of life rather than a problem to be solved. The challenge is, for education systems, to provide a quality education that considers learners' needs while balancing them out with social, political, and cultural demands. Kirkpatrick (2019), in a discussion of the role of English in Asia, re-defined the role of English with the following words: "primary role of English plays through Asia is a lingua franca, as a language of communication for Asian themselves [rather than talking to native speakers]" (p.191). Kirkpatrick, supporting English as the de facto of South East Asian countries, recommended ELT curriculum of Asia needed to change to the type of curriculum that includes and presents cultures of locals of Asia. Kirkpatrick (2019) listed the following six principles related to English language education:

Principle (1) the native speaker of English is not the linguistic target. Mutual intelligibility is the goal.

Principle (2) the native speaker's culture is not the cultural target. Intercultural competence in relevant cultures is the goal.

Principle (3) multilinguals who are suitably trained provide the most appropriate English language teachers.

Principle (4) lingua franca environments provide excellent learning environments for lingua franca speakers.

Principle (5) Spoken is not the same as written.

Principle (6) Assessment must be relevant to the ASEAN context. 
(Kirkpatrick, 2019, p. 199).

\subsection{A dimension of multilingual education: multiliteracy education for Syrian refugee children}

ELF is a social phenomenon considering language in constant transformation moving beyond traditional instructional routines, authentic language use and elaboration of the construction of meaning via languaging. Languaging is the employment of any linguistic tool to achieve communicative aims (Jørgensen, 2008) and the use of it often necessitates adaptation and manipulation of the language to provide a common ground that is beyond native speaker model (Wei, 2017). Multilingual and multicultural contexts necessitate becoming culturally sensitive to the diversity of contexts in which English is used, identifying the degree(s) of acceptance. A revamped language education considers language awareness activities focusing on intelligibility and communication, rather than mere focus on form (Bayyurt \& Sifakis, 2015a).

Language learning is not a straightforward process. Rather it is dynamic, continuous, and unpredictable; therefore, it is not meaningful to try to follow a predictable path. Baker (2011) reported numerous views of literacy education and discussed the functionality of literacy for bilingual children education. Basic skills in learning to read are phonemic awareness, phonics, fluency, vocabulary, and comprehension (August \& Shanahan, 2006). Another literacy model suggest literacy is memorization, transmitting the moral values. While school plays a crucial role in multiliteracy development, the development of literacy practices is highly influenced by the family and the community. Literacy ensures access to economic, personal, and social advancement for the immigrants. Bialystok (2001): "Literacy is the ticket entry into our society, it is the currency by which social and economic positions are waged, and it is the central purpose of schooling" (p.152). August and Shanahan (2006) further added "linguistic minorities who can't read or write in the [target] language cannot fully participate in schools, workplaces, or the society" (p .1-2).

Other than an essential human right, language is a personal, community, and regional resource. As a dimension of additive bilingualism where minority options are preserved, languages are seen as a cultural, linguistic, and social resource with bridge building potential across different groups to increase intercultural awareness and communication. In this section, viewpoints proposing the nature of biliteracy and multiliteracies for bilinguals will be presented and related to the case of Syrian refugees in Turkey. While literacy is to enculturate and assimilate the newcomers into the hosting culture and the society, some others claim it is a social practice that highlights diversity of literary practices according to genres, styles, domains and social identities. The table 2 will lay out the most salient points of the views related to literacy for minority students. 
Table 2. Literacy approaches for language minority students

\begin{tabular}{|c|c|c|c|c|}
\hline Approaches to Literacy & Emphasis & Pedagogic Instructional factors & $\begin{array}{l}\text { Socio-cultural and } \\
\text { socio-political factors }\end{array}$ & Syrian Minority Students \\
\hline The Skills Approach & $\begin{array}{l}\text { Two literacy skills: } \\
\text { writing and reading }\end{array}$ & $\begin{array}{l}\text {-Phonemic awareness, phonics, fluency, } \\
\text { vocabulary, comprehension and oracy. } \\
\text {-explicit and implicit instruction } \\
\text {-standardized, decontextualized assessment } \\
\text { procedures }\end{array}$ & \multirow[t]{2}{*}{$\begin{array}{l}\text { - full functional } \\
\text { literacy }=\text { smooth } \\
\text { integration of the } \\
\text { person to the society }\end{array}$} & \\
\hline $\begin{array}{l}\text { The Construction of Meaning } \\
\text { Approach }\end{array}$ & $\begin{array}{l}\text {-reliance on minority } \\
\text { language, culture, } \\
\text { history, social contexts }\end{array}$ & $\begin{array}{l}\text { - learning mediated by the social interaction } \\
\text { between the child, the teacher, and the parent } \\
\text { - literacy materials interpretation varies } \\
\text { depending on background } \\
\text {-peer modelling, coaching to mediate meaning } \\
\text { construction, scaffolding, Zone of Proximal } \\
\text { Development }\end{array}$ & & \\
\hline \multirow[t]{2}{*}{$\begin{array}{l}\text { The Sociocultural Literacy } \\
\text { Approach }\end{array}$} & \multirow[t]{2}{*}{$\begin{array}{l}\text {-literacies are social } \\
\text { practices: reading and } \\
\text { writing are socially- } \\
\text { bounded }\end{array}$} & $\begin{array}{l}\text {-discourses } \\
\text { - cultural heritage internalized in reading. } \\
\text {-multicultural literacy providing a wider view of } \\
\text { the world, opening new horizons }\end{array}$ & $\begin{array}{l}\text {-assimilative or } \\
\text { cultural pluralist } \\
\text { viewpoint }\end{array}$ & $\begin{array}{l}\text {-minority children entering school } \\
\text { with different discourses than that of } \\
\text { school experience problems }\end{array}$ \\
\hline & & $\begin{array}{l}\text {-education is to teach correct, standard language } \\
\text { - education is a liberator that empowers }\end{array}$ & $\begin{array}{l}\text {-language of minorities } \\
\text { regarded as 'inferior' } \\
\text { 'deficient' }\end{array}$ & $\begin{array}{l}\text {-Syrian pupils can be exposed to } \\
\text { pieces reflecting diverse cultures } \\
\text { and attitudes }\end{array}$ \\
\hline \multirow{3}{*}{ The Critical Literacy Approach } & $\begin{array}{l}\text {-all meaning is socially } \\
\text { constructed }\end{array}$ & - literacy must go beyond basic skills of reading & & $\begin{array}{l}\text {-diversity of understanding to be } \\
\text { celebrated }\end{array}$ \\
\hline & $\begin{array}{l}\text {-literacy is to imbue } \\
\text { minority children with } \\
\text { central beliefs, attitudes }\end{array}$ & and writing & & $\begin{array}{l}\text {-creative reading act could be } \\
\text { practiced }\end{array}$ \\
\hline & -multiliteracies & & & \\
\hline
\end{tabular}


Children who learn to read in more than one language early on has cognitive and linguistic advantages compared to monolingual peers. As reported by Bialystok (1997, 2001), children familiar with print and story in two languages are capable of grasping the arbitrary connection between the print and the meaning. Exposure to multiple languages mediates appreciation of linguistic and cultural varieties. Literacy proficiency in the mother tongue is the indicator of a strong development of biliteracy skills, thus, children who gain more literacy skills in their home language are likely to learn to read in the target language with more success (August \&Shanahan, 2006). The take-home message from the reported cases of success in the target language reading when home language literacy skills are supported could provide Syrian refugee children with chances of improving their reading and writing skills in Arabic and Turkish. The materials and instructional practices at TECs are not reported in this study. Even though Arabic textbooks prepared for native Turkish pupils are available on EBA- the official online platform of Turkey's MONE- there has been no study or project that prepares educational materials specifically for Syrian minority children other than Uyum Projesi- Compliance Project- by Directorate of Immigration Affairs materials targeting at Turkish and Syrian children. In this project, short storybooks, coloring pages, stories of appreciation were included (See Figure 2).

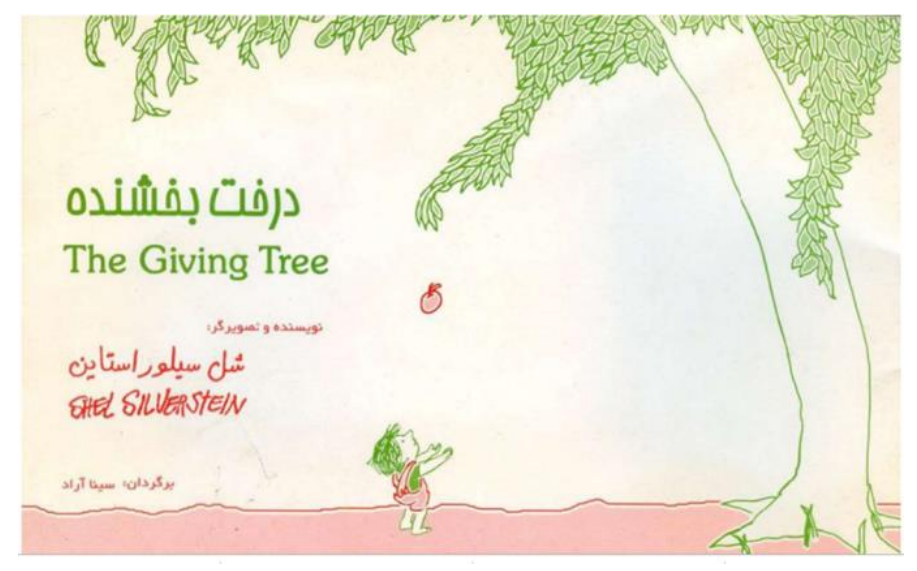

Figure 2. The Giving Tree by Shel Silverstein in Arabic and English

Home language instruction for language minority students (e.g. Syrian refugee children in Turkey) bring along several issues such as lack of educational materials and instructor training. Occasionally, the issue emerges from the fact that the minority language does not have a grammar system or is only spoken-there is no writing system. Arabic is based on a different writing system than Turkish and it differs from Turkish orthographically speaking. However, lexical overlap between the languages, cultural (dis)similarities as transferrable knowledge and skills could be highlighted so minority children become culturally and linguistically literate in Arabic and Turkish.

Literacy development in the second language should have no cost on the literacy knowledge and skills development in the mother tongue. In other words, additive 
bilingualism with opportunities of reading and writing in the mother tongue, further exploration of the mother tongue culture can enrich overall biliteracy development.

\subsection{The stake-holders of effective biliteracy development}

a) School Resources: Multiliteracies, multiculturalism celebrated, appreciated, and encouraged in the school context via culturally diverse displays, heritage language recognition and integration to education, culturally-related books in which native culture and history are a few of educational resources to ensure multilingual and multicultural literacy development. Dual language books, written in two (possibly more) languages can act as a major bridge connecting home to school. Language minority students could make the best out of the dual language book if it is written from the home language and culture perspective (See Figure 2). Occasionally, dual books have an Anglo-centric perspective and translated to minority languages (see Figure 3) without focusing on mutual values. Syrian refugee children, with the help of dual language books, could do leisurely reading with parents and family at home or could read the story, discuss and complete follow-up activities with Turkish and Syrian classmates at school.
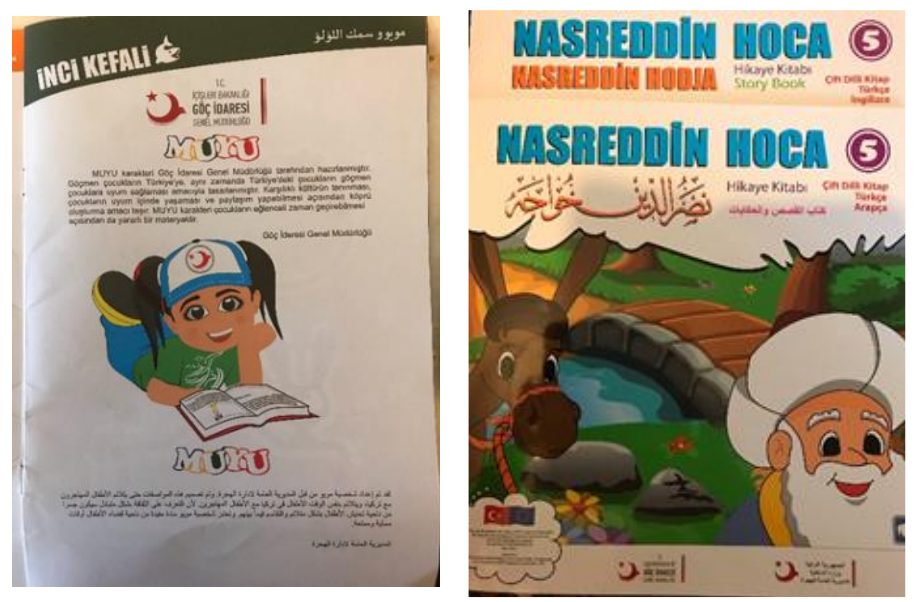

Figure 3. Materials by Turkey's General Directorate of Immigration Affairs

b) Community Relationships: Biliteracy development has strong ties with the community which paves the way to literacy practice orientations, processes and resources. In the community surrounding the child, the literacy practices could be regarded as functional for an integration to the society or for employment purposes or recreational interests such as self-enjoyment. In Turkey, for a stronger multiliteracy and multicultural development of Syrian refugee children, families and the larger community in the immediate circle of the refugee children should work in collaboration with the schools and the educators. Literacy is not in isolation of the societal practices. Instead, it is highly culturally and socially-bound; therefore, host communities need to be incorporated to enrich mastery of different literacy practices. 
c) Home and School Connection: Families, including parental education and homebased literacy activities, have an immense role in students' multiliteracy development. Older siblings, for instance, could help with school homework or a mother could listen to her child read the storybook. Home, with lots of print and audio materials of the host language, can serve as a rich resource for the child to practice all four skills. In an ethnography research studying three communities and home-based literacy-oriented practices and discussing varying types of literacy orientations and practices, Brice-Heath (1982) reported certain tendencies of literacy-oriented engagement pertaining to a community. For instance, reading cycles, book reading is like a dialogue with turn taking and asking wh-questions with no extension of content with an anecdotal commentaries was the observation in one of the communities. This seminal work clearly revealed different literacy traditions and practices across communities and concluded literacy practice patterns, tendencies need to be interpreted in relation to sociocultural factors.

\section{Conclusion}

The present position paper is an attempt to examine Syrian refugee children case in Turkey through the perspectives of ELF, multicultural and multiliteracy education. The paper aimed to build bridges between refugee children and their education and echoes of ELF through multicultural and multilingual education principles. The basic human rights of Syrian refugee children to receive education in their mother tongue encountered financial, educational, socio-political obstacles and resulted in a longterm conflict jeopardizing the future of refugee children and the future of the entire country. Turkey, trying to integrate the newcomers to the society and other systems of the nation, has had Syrian refugee children education initiatives that are not multicultural and multilingual. Nieto (1994) reported binaries setting multicultural education and setting steps beyond tolerance is one essential keystone to be enriched with "acceptance, respect, and finally affirmation, solidarity, and critique" (p. 2). Content integration, according to Banks (1998), is the affirmation of recognizing the minority group in the curricula. Learners, via knowledge construction, will deconstruct knowledge associated with the dominating or minority society. Moving beyond stereotypes is one example of knowledge re-construction by reducing labeling and increasing appreciation of racial, socio-cultural, linguistic differences and empowering one another as members of a culturally diverse one big family. Teacher education, in light of current perspectives on pedagogy for ELF (Bayyurt \& Akcan, 2015) and research perspectives on teaching and learning English in Turkey (Bayyurt \& Bektaş- Çetinkaya, 2012) can gauge the needs of Turkey's education system with the arrival of Syrian refugee children and shed light on the emerging research and practice in the relevant field. In the provision of education for Syrian refugee children, a holistic approach adoption with a welcoming, racism-free environment that cares not only for academic success but also for psycho-social needs is what is recommended for an inclusive education (Taylor \& Sidhu, 2012). A diversity imperative is culturally responsive school ethos with a site-based school management, a strong diversity 
training of teaching staff, curriculum and instruction bridging cultures, and partnerships with family and communities (Johnson, 2003). The framework presented here aims to commit success of all through a systematic effort of all stake-holders including educators, policy-makers, curriculum-designers, families, communities and all others.

\section{References}

Arnot, M., \& Pinson, H. (2005). The education of asylum-seeker and refugee children: A study of LEA and school values, policies and practices. Cambridge: Faculty of Education, University of Cambridge.

August, D., \& Shanahan, T. (Eds.). (2006). Developing literacy in second-language learners: Report of the national literacy panel on language minority children and youth. Mahwah, NJ: Lawrence Erlbaum Associates.

Aydın, H. \& Kaya, Y. (2019). Education for Syrian refugees: the new global issue facing teachers and principals in Turkey. Educational Studies, 55, 46-71. doi: 10.1080/00131946.2018.1561454.

Azuaga, L. \& Cavalheiro, L. (2015). Bringing new ELT policies an ELF to teacher training courses. In Y. Bayyurt, \& S. Akcan (Eds.), Current perspectives on pedagogy for English as a lingua franca, (pp.103-120). Berlin: De Gruyter.

Baker, C. (2011). Foundations of bilingual education and bilingualism. Bristol, UK: Multilingual Matters.

Banks, J. (2008). Diversity, group identity, and citizenship education in a global age. Educational Researcher, 37 (3), 129-139. doi:10.3102/0013189X08317501.

Banks, J. (1998). Multiculturalism's five dimensions. (Interview).

Banks, J. A, \& Banks, C. A. (2010). Multicultural education: issues and perspectives (7th ed). Hoboken, NJ: Wiley.

Blair, A. (2015). Evolving a post-native, multilingual model for ELF-aware teacher education. In Y. Bayyurt, \& S. Akcan (Eds.), Current perspectives on pedagogy for English as a lingua franca, (pp.89-102). Berlin: De Gruyter.

Bayyurt, Y. (2013). Current perspectives on sociolinguistics and English language education. The Journal of Language Teaching and Learning, 1, 69-78.

Bayyurt, Y. (2012). Proposing a model for English language education in the Turkish sociocultural context. In Y. Bayyurt \& Y. Bektaş-Çetinkaya (Eds.), Research perspectives on teaching and learning English in Turkey, (pp. 301-312). Frankfurt: Peter Lang.

Bayyurt, Y. \& Akcan, S. (2015). Current perspectives on pedagogy for ELF. In Y. Bayyurt, \& S. Akcan (Eds.), Current perspectives on pedagogy for English as a lingua franca, (pp.1-9). Berlin: De Gruyter.

Bayyurt, Y. \& Bektaş-Çetinkaya, Y. (2012). Introduction. In Y. Bayyurt \& Y. BektaşÇetinkaya (Eds.), Research perspectives on teaching and learning English in Turkey, (pp. 17-22). Frankfurt: Peter Lang.

Bayyurt, Y. \& Sifakis, N. C. (2015a). Developing an ELF-aware pedagogy: insights from a selfeducation programme. In P. Vettorel (Ed.), New frontiers in teaching and learning English, pp. 55-76). Newcastle upon Tyne: Cambridge Scholars Publishing.

Bayyurt, Y. \& Sifakis, N. C. (2015b). ELF-aware in-service teacher education: a transformative perspective. In H. Bowles \& A. Cogo (Eds.), International perspectives on English as a lingua franca: Pedagogical Insights, (pp. 117-136). Basingstoke, UK: Palgrave. 
Bektaş-Çetinkaya, Y. \& Börkan, B. (2012). Intercultural communicative competence of preservice language teachers in Turkey. In Y. Bayyurt \& Y. Bektaş-Çetinkaya (Eds.), Research perspectives on teaching and learning English in Turkey, (pp. 17-22). Frankfurt: Peter Lang.

Bialystok, E. (2001). Bilingualism in development: Language, literacy, and cognition. New York, NY, US: Cambridge University Press.

Bialystok, E. (1997). The structure of age: in search of barriers to second language acquisition. Second Language Research, 13 (2), 116-137.

Biricik Deniz, E.,Özkan, Y., \& Bayyurt, Y. (2016). English as a lingua franca: reflections on ELF-related issues by pre-service English language teachers in Turkey. The Reading Matrix: An International Online Journal, 16 (2), 144-161.

Brice Heath, S. (1982). What no bedtime story means: narrative skills at home and school. Language in Society, 11, 49-76.

Cenoz, J. (2013). Defining Multilingualism. Annual Review of Applied Linguistics, 33, 3-18. doi:10.1017/S026719051300007X

Cummins, J. (2000). Language, power and pedagogy: bilingual children in the crossfire. Clevedon: Multilingual Matters.

Çelik, Ç., \& İçduygu, A. (2018), 'Schools and refugee children: the case of Syrians in Turkey', International Migration, 57 (2), 253-267. doi.org/10.1111/imig.12488

Directorate General of Immigration Affairs. (Göç İdaresi Strateji Belgesi) Retrieved from https://www.goc.gov.tr/ (Accessed November 25 2018).

http://www.goc.gov.tr/icerik6/turkiye\%E2\%80\%99nin-avrupa-birligine-katilim-surecindeiltica-alaninda-yapilmasi-ongorulen-calismalara-iliskin-strateji-belgesi_344_696_697_icerik

Doğançay-Aktuna. S. (2006). Expanding the socio-cultural knowledge base of TESOL teacher education. Language, Culture and Curriculum, 19, 278-295.

Gürsoy, E.\& Ertaşoğlu, L. D. (2019). Syrian refugees' perception of barriers and bridges towards integration into Turkish society. Language, Culture, and Curriculum, 32, 128-141, doi: 10.1080/07908318.2018.1542000.

Hornberger, N. H. (2003). Continua of biliteracy: an ecological framework for educational policy, research, and practice in multilingual setting, Clevedon: Multilingual Matters.

Human Rights Watch Report. (2015). 'When I picture my future, I see nothing' barriers to education for Syrian refugee children in Turkey. Retrieved from https://www.hrw.org/et/node/283247

İçduygu, A., \& Sert, D. S. (2019). Introduction: Syrian refugees- Facing challenges, making choices. International Migration, 57, 121-125.

Jenkins, J. (2006). Current perspectives on teaching world Englishes and English as a lingua franca. TESOL Quarterly, 40, 157-181.

Johnson, L. S. (2003). The diversity imperative: building a culturally responsive school ethos. Intercultural Education, 14, 17-30, doi: 10.1080/1467598032000044629.

Jørgensen, N.J. (2008) Polylingual languaging around and among children and adolescents. International Journal of Multilingualism 5 (3), 161-176.

Kachru, B. (1985). Standards, codification and sociolinguistic realism: The English language in the outer circle. In R. Quirk \& H. G. Widdowson (Eds.), English in the world: teaching and learning the language and literatures, (pp. 11-30). Cambridge: Cambridge University Press.

Kaplan, R. B. \& Baldauf, R. B. (1997). Language planning from practice to theory. Clevedon: Multilingual Matters. 
Kirkpatrick, A. (2019). From EFL to ELF: the time is right. In S. Zein (Ed.), Teacher education for English as a lingua franca: perspectives from Indonesia, (pp. 191-203). New York: Routledge.

Kirkpartick, A. (2010). English as a lingua franca in ASEAN. Hong Kong: Hong Kong University Press.

Llurda, E., Bayyurt, Y., \& Sifakis, N. (2017). Raising teachers' awareness about English and English as a lingua franca. In P. Garrett \& J. M. Cots (Eds.) The Routledge handbook of language awareness, (pp. 155-169). Routledge.

May, S. (1994). Making multicultural education work. Bristol: Longdunn.

McKay, S. (2004). Teaching English as an international language: the role of culture in Asian contexts. The Journal of Asia TEFL, 1, pp.1-22.

MoNE (2016). Suriyeli Öğrenciler için 4 Bin 200 Öğretmen Alımı Yapılacak (Four Thousand Two Hundred Teachers Will Be Hired For Syrian Students). Retrieved from http://www.meb.gov.tr/suriyeli-ogrenciler-icin-4-bin-200-ogretmenalimiyapilacak/haber/12204/tr (Accessed 15 November 2016).

Multeciler Dernegi. https://multeciler.org.tr/turkiyedeki-suriyeli-sayisi/ Suriyeli Gocmen Sayisi Retrieved January 2019.

Nieto, S. (2001). Language, culture, and teaching: critical perspectives for a new century. Routledge.

Nieto, S. (1994). Affirmation, solidarity, and critique: moving beyond tolerance in multicultural education. Multicultural Education, 1 (3), 9-12.

OECD (2008). Policy Brief: Ten Steps to Equity in Education Retrieved from https://www.oecd.org/education/school/39989494.pdf

Pennycook, A. (2008). Changing practices in global ELT. Paper presented at IATEFL, Exeter, UK.

Seidlhofer, B. (2001). Closing a conceptual gap: the case for a description of English as a lingua franca. International Journal of Applied Linguistics, 11, 133-158.

Sidhu, R., \& Taylor, S. (2007). Educational provision for refugee youth in Australia: left to chance? Journal of Sociology, 43 (3), 283-300.

Skutnabb-Kangas, T. (2000). Linguistic genocide in education or worldwide diversity and human rights? Mahwah, NJ: Erlbaum.

Skutnabb-Kangas, T. (1981). Bilingualism or not: the education of minorities. Multilingual Matters.

Skutnabb-Kangas, T., \& McCarty, T. (2008). Key concepts in bilingual education: Ideological, historical, epistemological, and empirical foundations. In J. Cummins \& N. Hornberger (Eds.), Encyclopedia of language and education: Bilingual education ( $2^{\text {nd }}$ ed., Vol. 5, pp. 317). New York, NY: Springer.

Şimşek, D. (2019). Transnational activities of Syrian refugees in Turkey: hindering or supporting integration. International Migration, 57 (2), 268-282.

Şirin, S. R., \& Aber, L. (Eds.). (2018). Syrian refugee children. Vulnerable Children and Youth Studies, 13, 1-6.

Taşkın, P. \& Erdemli, P. (2018). Education for Syrian refugees: problems faced by teachers in Turkey. Eurasian Journal of Educational Research, 75, 155-178.

Taylor, S., \& Sidhu, R. K. (2012). Supporting refugee students in schools: what constitutes inclusive education? International Journal of Inclusive Education, 16, 39-56.

TURKSAM http://turksam.org/turksam-goc-gocmen-bulteni-15-ocak-2019

UNHCR. (2018). Registered Syrian Refugees in Turkey. Retrieved from https://data2.unher.org/en/situations/syria/ location/113 
Uzun, M. \& Bütün, E. (2016). Okul öncesi eğitim kurumlarındaki Suriyeli sığınmacı çocukların karşılaştıkları sorunlar hakkında öğretmen görüşleri. Uluslararası Erken Çocukluk Eğitimi Çalışmaları Dergisi, 1 (1), 72-83.

Üzüm, B., Yazan, B., Avineri, N., Akayoğlu. S. (2019). Preservice teachers' discursive constructions of cultural practices in a multicultural telecollaboration. International Journal of Multicultural Education, 21, 82-104.

Wei, L. (2017). Translanguaging as a practical theory of language. Applied Linguistics, 39, 123.

\section{Copyrights}

Copyright for this article is retained by the author(s), with first publication rights granted to the Journal.

This is an open-access article distributed under the terms and conditions of the Creative Commons Attribution license (CC BY-NC-ND) (http://creativecommons.org/licenses/by-nc-nd/4.0/). 